\title{
Impact of beta-blocker therapy on thoracic aorta 3D wall shear stress in patients with bicuspid aortic valve
}

\author{
Bradley D Allen ${ }^{1 *}$, Pim van Ooij ${ }^{1}$, Alex J Barker ${ }^{1}$, Jeremy D Collins ${ }^{1}$, James C Carr ${ }^{1}$, Michael Markl ${ }^{1,2}$, Preeti Kansal $^{3}$ \\ From 17th Annual SCMR Scientific Sessions \\ New Orleans, LA, USA. 16-19 January 2014
}

\section{Background}

Beta-blockers are the recommended medical treatment for slowing ascending aorta (AAo) dilation in patients with bicuspid aortic valve (BAV). Wall shear stress (WSS) has been shown to promote endothelial cell dysfunction [1] and AAo WSS may play a role in aortic aneurysm growth. Time-resolved 3D phase contrast (4D flow) MRI allows for the quantification of 3D WSS regionally in the thoracic aorta. The aim of this study was to assess changes in thoracic aorta WSS associated with $\beta$-blocker therapy in BAV patients.

\section{Methods}

BAV patients on $\beta$-blockers $(\mathrm{BB}+)(\mathrm{n}=10, \mathrm{M}: \mathrm{F}=8: 2$, age: $53 \pm 11$ years) or not on $\beta$-blockers (BB-) $(n=10$, $\mathrm{M}: \mathrm{F}=9: 1$, age: $51 \pm 15$ years) underwent $4 \mathrm{D}$ flow MRI as part of this IRB-approved study. Groups were matched by BAV morphology (all right-left fusion), systolic blood pressure (BB+: $137 \pm 12 \mathrm{mmHg}, \mathrm{BB}$-: $132 \pm$ $17 \mathrm{mmHg}, \mathrm{p}=0.48$ ), degree of aortic stenosis, and AAo diameter $(\mathrm{BB}+: 4.1 \pm 0.7 \mathrm{~cm}, \mathrm{BB}-: 3.6 \pm 0.4 \mathrm{~cm}, \mathrm{p}=$ 0.07). Five patients in each group were concurrently treated with ACE-inhibitors or angiotensin receptor blockers. Data analysis included correction for eddy currents and velocity aliasing and 3D segmentation of the thoracic aorta (MIMICS, Materlise, Belgium). Peak systolic WSS (WSS sys $_{\text {s }}$ ) was calculated within the vessel using the method described by van Ooij[2]. The aorta was divided into ascending, arch, and descending regions, and max and mean $\mathrm{WSS}_{\text {sys }}$ were calculated in each region. $\mathrm{WSS}_{\text {sys }}$ maximum intensity projections (MIP) were mapped onto a sagittal view of each aorta

${ }^{1}$ Radiology, Northwestern University, Chicago, Illinois, USA Full list of author information is available at the end of the article for visual comparison. Quantitative results were compared using Student's t-test. Spearman $\left(\mathrm{r}_{\mathrm{S}}\right)$ or Pearson (r) correlation was performed as appropriate.

\section{Results}

No statistical difference in max or mean $\mathrm{WSS}_{\text {sys }}$ was observed between $\mathrm{BB}+$ and $\mathrm{BB}$ - groups at any region along the aorta, although values were consistently lower in the $\mathrm{BB}+$ group (Table 1). Max $\mathrm{WSS}_{\text {sys }}$ in the AAo showed no correlation with aortic diameter $(\mathrm{r}=.289$, $\mathrm{p}=0.22$ ) but did correlate with the degree of aortic ste-

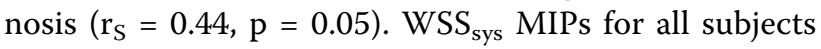
are shown in Figure 1. The magnitude and regional distribution of $\mathrm{WSS}_{\text {sys }}$ was highly variable between individuals for both groups. Decreased eccentricity of WSS in the AAo was observed in $\mathrm{BB}+$ patients.

\section{Conclusions}

Our results suggest that the impact of $\beta$-blocker therapy on the degree of WSS in the thoracic aorta is limited, but treatment may alter AAo WSS distribution. The high inter-individual variability of 3D WSS highlights the potential diagnostic value of 4D flow MRI WSS

Table 1 Max and mean peak systolic wall shear stress (WSS $_{\text {sys }}$ ) regionally along the aorta in bicuspid aortic valve patients being treated with beta-blockers $(\mathrm{BB}+)$ or not receiving beta-blockers (BB-).

\begin{tabular}{|c|c|c|c|c|c|c|}
\hline & \multicolumn{3}{|c|}{ Max WSS $\left(\mathrm{N} / \mathrm{m}^{2}\right)$} & \multicolumn{3}{|c|}{ Mean WSS $\left(\mathrm{N} / \mathrm{m}^{2}\right)$} \\
\hline & $\mathrm{BB}+$ & BB- & p-value & $\mathrm{BB}+$ & BB- & $p$-value \\
\hline $\begin{array}{l}\text { Ascending } \\
\text { Aorta }\end{array}$ & $2.9 \pm 1.7$ & $3.2 \pm 1.8$ & 0.70 & $0.9 \pm 0.3$ & $1.0 \pm 0.4$ & 0.40 \\
\hline Arch & $1.7 \pm 0.5$ & $2.3 \pm 1.2$ & 0.20 & $0.9 \pm 0.3$ & $1.2 \pm 0.5$ & 0.15 \\
\hline $\begin{array}{l}\text { Descending } \\
\text { Aorta }\end{array}$ & $2.1 \pm 0.8$ & $2.4 \pm 1.1$ & 0.57 & $1.3 \pm 0.4$ & $1.4 \pm 0.1$ & 0.66 \\
\hline
\end{tabular}




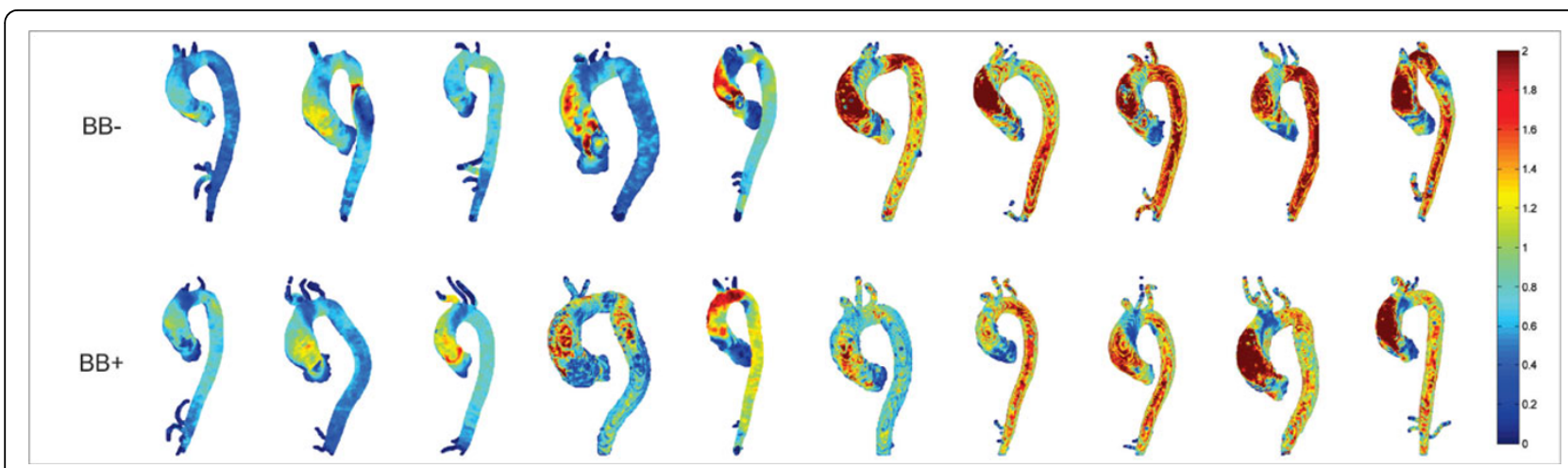

Figure 1 Peak Systolic Wall Shear Stress $\left(\right.$ WSS $_{\text {sys }}$ ) maximum intensity projections in the study cohort. Values for WSS sys are in N/m². Note

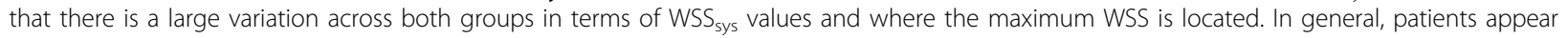
to have WSS $_{\text {sys }}$ angled toward the lateral wall of the ascending aorta, however, there appears to be fewer patients with this eccentric WSS distribution in the $\beta$-blocker group (BB+).

quantification for individualized assessment $\beta$-blocker effectiveness in BAV aortopathy. A prospective study in a large number of patients pre- and post-treatment is required to better isolate the impact of $\beta$-blockers in this population.

\section{Funding}

NIH NCI 5R25CA132822-04, NIH NHLBI R01HL115828; AHA13SDG14360004, BAV Program at the Bluhm Cardiovascular Institute.

\section{Authors' details}

${ }^{1}$ Radiology, Northwestern University, Chicago, Illinois, USA. ${ }^{2}$ Biomedical Engineering, Norhtwestern University, Chicago, Illinois, USA. ${ }^{3}$ Medicine Cardiology, Norhtwestern University, Chicago, Illinois, USA.

Published: 16 January 2014

\section{References}

1. Reneman RS, et al: J Vasc Res 2006, 43(3):251-269.

2. van Ooij P, et al: J Magn Reson Imaging 2013.

doi:10.1186/1532-429X-16-S1-047

Cite this article as: Allen et al:: Impact of beta-blocker therapy on thoracic aorta 3D wall shear stress in patients with bicuspid aortic valve. Journal of Cardiovascular Magnetic Resonance 2014 16(Suppl 1):047.
Submit your next manuscript to BioMed Central and take full advantage of:

- Convenient online submission

- Thorough peer review

- No space constraints or color figure charges

- Immediate publication on acceptance

- Inclusion in PubMed, CAS, Scopus and Google Scholar

- Research which is freely available for redistribution 